\title{
Pengaruh Latar Belakang Pendidikan dan Pengalaman Politik terhadap Kinerja DPRD dalam Pengawasan Pengelolaan Keuangan Daerah/APBD
}

\author{
Ferdinant Nuru \\ Lidya Mawikere
}

\begin{abstract}
This study aimed to examine the effect of level of education and political experience to Performance Oversight Council in Financial Management / Budget.

The data used in this study is primary data and instruments in this study is a questionnaire that is processed using SPSS 19. The subjects were Sorong legislators who were 30. Of the 30 questionnaires distributed, returned and can be evaluated in a total of 29 questionnaires. The method used in this study is a multiple linear regression. To test the hypothesis used simultan eously $F$ test and used partial eously t test.

The results and hypothesis testing shows that the variables together education and political experience influence the performance of Parliament in monitoring the financial management area / budget. Partially only political experience that affect the performance of Parliament in monitoring regional financial management / budget, while the level of education does not affect the performance of the Council in the area of supervision of financial management / budget. Educational level was not affected due to lack of competence backed by councilors.
\end{abstract}

Keywords: Level Of Education, Political Experience And Performance Oversight Council In Financial Management / Budget 


\section{PENDAHULUAN}

\subsection{Latar Belakang Masalah}

Dikeluarkan dan diberlakukannya Undang-Undang Nomor : 22 Tahun 1999 yang kemudian direvisi menjadi Undang-Undang Nomor : 32 Tahun 2004 Tentang Pemerintahan Daerah dan UndangUndang Nomor : 25 Tahun 1999 yang kemudian direvisi menjadi Undang-Undang Nomor : 33 Tahun 2004 Tentang Perimbangan Keuangan Antara Pemerintah Pusat dan Daerah merupakan awal dilakukannya desentralisasi untuk mewujudkan otonomi daerah. Salah satu aspek penting dalam rangka pelaksanaan otonomi daerah dan desentralisasi adalah masalah Pengelolaan Keuangan Daerah dan Anggaran Pendapatan dan Belanja Daerah (APBD). Untuk mewujudkan otonomi daerah dan desentralisasi yang luas, nyata, dan bertanggungjawab diperlukan manajemen keuangan daerah yang mampu mengontrol kebijakan keuangan daerah secara ekonomis, efisien, efektif, transparan, dan akuntabel.

Peran lembaga eksekutif bagi pelayanan publik terus meningkat setiap tahun, hal ini tentunya akan menuntut lembaga legislatif dalam pengawasan pengelolaan keuangan daerah untuk meningkatkan kinerjanya lebih baik lagi. Untuk mendapatkan kinerja yang baik dituntut adanya sumber daya manusia yang berkualitas. Indikator sumber daya manusia yang berkualitas diantaranya adalah pendidikan dan pengalaman. Latar belakang pendidikan yang tinggi akan mampu membantu seseorang menyelesaikan tugasnya dengan baik. Kesesuaian latar belakang pendidikan akan berpengaruh terhadap kinerja seseorang. Setiap orang yang mempunyai latar belakang pendidikan yang sesuai dengan bidang pekerjaan atau tugasnya akan lebih mengerti tentang masalah atau pekerjaan yang sedang dihadapinya. Masa kerja yang lebih lama bagi anggota legislatif juga akan berdampak pada pengalaman dalam menghadapi dan menyelesaikan masalah-masalah pemerintahan khususnya dalam menjalankan fungsi pengawasan. Oleh karena itu kualitas sumber daya manusia juga ditentukan oleh masa kerja atau lamanya menjabat sebagai pengurus partai ataupun sebagai anggota legislatif bagi para anggota dewan.

Berdasarkan uraian serta penjelasan di atas, maka sangat jelas bahwa peran DPRD dalam pengawasan keuangan daerah sangat besar dan memiliki nilai yang sangat strategis untuk dapat mengontrol kebijakan keuangan daerah secara ekonomis, efisien, efektif, transparan, dan akuntabel. Namun kenyataan yang terjadi selama ini, bahwa masih banyak permasalahan dan kelemahan dalam pengelolaan keuangan daerah yang dilaksanakan lembaga eksekutif yang tidak dapat dikontrol dengan baik oleh lembaga legislatif karena masih rendahnya peranan DPRD dalam keseluruhan proses atau siklus anggaran, baik dalam hal perencanaan, pelaksanaan, pelaporan maupun pengawasan program kerja eksekutif. Rendahnya peran legislatif ini terjadi karena dipengaruhi oleh berbagai faktor yang telah diuraikan di atas antara lain yaitu, latar belakang pendidikan dan pengalaman politik. Hal inilah yang menjadi pertimbangan peneliti untuk meneliti kembali faktor-faktor yang mempengaruhi kinerja DPRD dalam pengawasan pengelolaan keuangan daerah. Faktor-faktor tersebut akan mempengaruhi kinerja dewan dalam pengawasan pengelolaan keuangan daerah yang akan berdampak pada program kerja yang ada dalam anggaran daerah belum dilaksanakan sesuai dengan prioritas dan preferensi daerah. Dari uraian faktor-faktor di atas, maka peneliti memutuskan untuk meneliti dua faktor yang merupakan variabel independen $(\mathrm{X})$ yaitu latar belakang pendidikan dan pengalaman politik; dengan variabel dependen (Y) yaitu Kinerja DPRD dalam pengawasan pengelolaan keuangan daerah.

Metode yang digunakan dalam penelitian ini adalah Library Research (penelitian Kepustakaan) dan Field Research (penelitian lapangan), yang dilakukan dengan cara survey atau kuesioner. Objek atau lokasi penelitian pada DPRD Kota Sorong dengan jangka waktu penelitian dimulai pada bulan Oktober 2012 sampai dengan November 2012. Teknik pengumpulan data dilakukan dengan menggunakan beberapa metode yaitu: Survey pendahuluan, Observasi/Studi lapangan, Wawancara dan kuesioner. 


\section{TINJAUAN PUSTAKA}

\subsection{Keuangan Daerah}

Keuangan daerah adalah semua hak dan kewajiban daerah dalam rangka penyelenggaraan pemerintahan daerah yang dapat dinilai dengan uang termasuk di dalamnya segala bentuk kekayaan yang berhubungan dengan hak dan kewajiban daerah tersebut dan tentunya dalam batas-batas kewenangan daerah (PP Nomor 58 Tahun 2005, Pasal 1 : 5). Sedangkan pasal 1 ayat 7 menyatakan bahwa APBD adalah rencana keuangan tahunan pemerintahan daerah yang dibahas dan disetujui bersama oleh pemerintah daerah dan DPRD, dan ditetapkan dengan peraturan daerah (Deddi Nordiawan, dkk, 2012, 39).

\subsection{Manajemen Keuangan Daerah}

Kepala daerah selaku kepala pemerintahan daerah adalah pemegang kekuasaan pengelolaan keuangan daerah dan mewakili pemerintah daerah dalam kepemilikan kekayaan daerah yang dipisahkan (Darise, N, 2009 : 18). Selaku pemegang kekuasaan pengelolaan keuangan daerah Kepalah Daerah mempunyai kewenangan :

1. Menetapkan kebijakan tentang pelaksanaan APBD.

2. Menetapkan kebijakan tentang pengelolaan barang daerah.

3. Menetapkan kuasa pengguna anggaran/barang.

4. Menetapkan bendahara penerimaan dan/atau bendahara pengeluaran

5. Menetapkan pejabat yang bertugas melakukan pemungutan penerimaan daerah

6. Menetapkan pejabat yang bertugas melakukan pengelolaan utang dan piutang daerah

7. Menetapkan pejabat yang bertugas melakukan pengelolaan barang milik daerah

8. Menetapkan pejabat yang bertugas melakukan pengelolaan pengujian atas tagihan dan memerintahkan pembayaran.

Kepalah Daerah selaku pemegang kekuasaan pengelolaan keuangan daerah melimpahkan sebagian atau seluruh kekuasaannya kepada :

1. Sekretaris Daerah selaku koordinator pengelola keuangan daerah. Yang dimaksud dengan koordinator adalah terkait dengan peran dan fungsi Sekretaris Daerah membantu Kepala Daerah dalam menyusun kebijakan dan mengkoordinasikan penyelenggaraan urusan pemerintahan daerah termasuk pengelolaan keuangan daerah dan bertanggungjawab atas pelaksanaan tugasnya Kepada Kepala Daerah

2. Kepala Satuan Kerja Pengelola Keuangan Daerah selaku PPKD mempunyai tugas melaksanakan pengelolaan APBD, dan segala bentuk kekayaan daerah lainnya serta bertindak sebagai Bendahara Umum Daerah (BUD).

3. Kepala Satuan Kerja Pemerintah Daerah (SKPD) selaku pengguna anggaran/barang daerah. Kepala satuan kerja perangkat daerah dalam menlaksanakan tugasnya sebagai pengguna anggaran dibantu oleh :

1) Pejabat kuasa pengguna angggaran (KUA)

2) Pejabat pelaksana teknis kegiatan (PPTK)

3) Pejabat piñata usaha keuangan (PPK)

4) Bendahara penerimaan dan pengeluaran. 


\subsection{Hubungan Latar Belakang Pendidikan Dengan Kinerja DPRD Dalam Pengawasan Pengelolaan Keuangan Daerah/APBD}

Pendidikan merupakan jenjang pendidikan yang ditempuh oleh seseorang. Pendidikan yang dimaksud di dalam penelitian ini adalah pendidikan formal dan non formal. Pendidikan formal yakni pendidikan persekolahan berupa jenjang pendidikan yang telah baku mulai dari jenjang SD sampai dengan perguruan tinggi. Pendidikan anggota dewan sangat penting diperhatikan karena pendidikan yang dimiliki seseorang akan mempengaruhi pola fikir, sikap dan tingkah laku mereka dalam melakukan suatu aktivitas. Sedangkan pendidikan non formal yakni pendidikan yang diperoleh melalui pelatihan/seminar. Anggota DPRD akan dapat melaksanakan tugas dan fungsinya dengan baik sebagai pengawas pengelolaan keuangan daerah apabila memiliki kemampuan dan pengetahuan mengenai penganggaran dan pengawasan anggaran. Oleh karena itu penting bagi anggota DPRD untuk mengikuti pelatihan/seminar mengenai penganggaran dan pengawasan anggaran untuk meningkatkan kinerjanya. Jika pendidikan yang dimiliki tidak sesuai dengan bidang tugasnya, maka pelatihan/seminar yang diikuti akan memberikan nilai tambah bagi anggota DPRD dalam memahami tugas dan fungsinya, dalam pengawasan pengelolaan keuangan daerah.

\subsection{Hubungan Pengalaman Politik Dengan Kinerja DPRD Dalam Pengawasan Pengelolaan Keuangan Daerah/APBD}

Pengalaman politik adalah pengalaman yang diperoleh seseorang dari menjadi anngota/pengurus suatu partai politik. Berapa pun lama menjabat di Partai Politik merupakan lama anggota dewan memegang jabatan dalam kepengurusan partai. DPRD akan dapat memainkan peranannya dengan baik apabila pimpinan dan anggota-anggotanya berada dalam kualifikasi ideal dalam arti memahami dengan benar hak, tugas dan wewenangnya dan mampu mengaplikasikannya secara baik, dan didukung dengan tingkat pendidikan dan pengalaman di bidang politik dan pemerintahan yang baik (Sari, 2010).

Kinerja (performance) adalah gambaran mengenai tingkat pencapaian pelaksanaan suatu kegiatan/program/kebijakan dalam mewujudkan sasaran, tujuan, misi dan visi organisasi yang tertuang dalam strategic planning suatu organisasi (Mohamad Mahsun, 2012, hal 25). Menurut PP No. 58 Tahun 2005 tentang Pengelolaan Keuangan Daerah, kinerja adalah keluaran/hasil dari kegiatan/program yang akan atau telah dicapai sehubungan dengan penggunaan anggaran dengan kuantitas dan kualitas yang terukur. Dari definisi tersebut dapat dikatakan bahwa kinerja DPRD dalam pengawasan keuangan daerah/APBD adalah keluaran/hasil dari kegiatan/program yang dicapai oleh anggota dewan dalam melaksanakan kegiatan atau tindakan pengawasan terhadap penggunaan APBD dengan kuantitas dan kualitas yang terukur yang didasarkan atas kompetensi, pengalaman, dan pengetahuan yang dimiliki oleh anggota dewan tersebut.

\section{GAMBARAN UMUM PEMERINTAH DAERAH KOTA SORONG}

Kota Sorong pada mulanya merupakan salah satu kecamatan yang dijadikan pusat pemerintahan Kabupaten Sorong. Namun dalam perkembangannya telah mengalami perubahan sesuai Peraturan Pemerintah No. 31 Tahun 1996 tanggal 3 Juni 1996 menjadi Kota Administratif Sorong. Selanjutnya berdasarkan Undang-Undang Nomot 45 Tahun 1999 Kota Administratif Sorong ditingkatkan statusnya menjadi daerah otonom sebagai Kota Sorong. Kemudian pada tanggal 12 Oktober 1999 bertempat di Jakarta dilaksanakan pelantikan Pejabat Walikota Sorong Drs. J. A. Jumame dan selanjutnya secara resmi Kota Sorong terpisah dari Kabupaten Sorong pada tanggal 28 Februari 2000 dengan ibu kota di Sorong. 


\section{ANALISIS DAN EVALUASI}

\subsection{Analisis Data}

Lokasi penelitian ini adalah Kantor DPRD Kota Sorong yang beralamat di Jln. Sungai Maruni KM 10, Distrik Sorong Timur, Provinsi Papua Barat. Populasi dan sampel dalam penelitian ini adalah seluruh anggota DPRD Kota Sorong untuk masa bhakti 2009-2014 sebanyak 30 orang. Kuesioner yang dibagikan kepada anggota dewan sebanyak 30 eksemplar sesuai dengan jumlah anggota dewan. Dari jumlah kuesioner yang dibagikan satu kuesioner tidak dapat terkumpul kembali dan 29 kuesioner yang terkumpul dapat dipergunakan sebagai data dalam penelitian ini. Analisis data selengkapnya adalah sebagai berikut :

1. Karakteristik responden

Karakteristik responden dapat dilihat berdasarkan jenis kelamin, usia, jenjang pendidikan, bidang pendidikan, pekerjaan sebelum menjadi anggota dewan, asal partai, pengalaman di partai, pengalaman sebagai anggota dewan dan asal komisi.

2. Pembagian Kelas Interval

Pembagian kelas berguna untuk menetukan seberapa banyak pilihan jawaban yang muncul atas kuesioner yang dikaitkan dengan hasil pengolahan data/tabulasi. Riduwan \& Sunarto, (2010 : 62) merumuskan panjang kelas sebagai berikut : $\mathrm{i}=\mathrm{R} / \mathrm{BK}$, dimana : $\mathrm{i}=$ Interval (Panjang Kelas), $\mathrm{R}=$ Rentangan (skor terbesar - skor terendah) dan $\mathrm{BK}=$ Banyaknya Kelas. Maka didapat hasil selisih dibagi jumlah 5 kelas adalah : 5-1/5=0,8.

Pembagian kelas sesuai rumus tersebut di atas dengan jarak antar kelas (interval) sebesar 0,8 seperti pada table 4.11 sebagai berikut :

Tabel 4.1

Pembagian interval kelas

\begin{tabular}{|c|c|cc|c|}
\hline No. & Kelas & \multicolumn{2}{|c|}{ Interval } & Keterangan \\
\hline 1 & I & $1,0-$ & $-1,8$ & Sangat tidak setuju \\
\hline 2 & II & $1,9-2,6$ & Tidak setuju \\
\hline 3 & III & $2,7-$ & $-3,4$ & Tidak Tahu \\
\hline 4 & IV & $3,5-$ & 4,2 & Setuju \\
\hline 5 & V & $4,3-5,0$ & Sangat setuju \\
\hline
\end{tabular}

Sumber : Data olahan 2013

Tabel 4.2

Total dan rata-rata jawaban responden Atas Pengukuran variabel dengan kelas interval

\begin{tabular}{|l|l|l|l|l|}
\hline $\begin{array}{l}\text { Variabel dan Ukuran } \\
\text { Variabel }\end{array}$ & Total & Rata-rata & Kelas & Keterangan \\
\hline Tingkat Pendidikan (X1) \\
\hline X1.1 & 106 & 3.7 & IV & Setuju \\
\hline X1.2 & 122 & 4.2 & IV & Setuju \\
\hline X1.3 & 124 & 4.3 & V & Sangat setuju \\
\hline X1.4 & 124 & 4.3 & V & Sangat setuju \\
\hline X1.5 & 123 & 4.2 & IV & Setuju \\
\hline X1.6 & 122 & 4.2 & IV & Setuju \\
\hline X1.7 & 128 & 4.4 & V & Sangat setuju \\
\hline Pengalaman Politik (X2) &
\end{tabular}




\begin{tabular}{|l|l|l|l|l|} 
X2.1 & 133 & 4.6 & V & Sangat setuju \\
\hline X2.2 & 133 & 4.6 & V & Sangat setuju \\
\hline X2.3 & 127 & 4.4 & V & Sangat setuju \\
\hline X2.4 & 129 & 4.4 & V & Sangat setuju \\
\hline X2.5 & 126 & 4.3 & V & Sangat setuju \\
\hline X2.6 & 124 & 4.3 & IV & Sangat setuju \\
\hline X2.7 & 127 & 4.4 & V & Sangat setuju \\
\hline Kinerja Anggota DPRD Dalam Pengawasan Keuangan Daerah/APBD (Y) \\
\hline Y.1 & 121 & 4.2 & IV & Setuju \\
\hline Y.2 & 123 & 4.2 & IV & Setuju \\
\hline Y.3 & 125 & 4.3 & V & Sangat setuju \\
\hline Y.4 & 121 & 4.2 & IV & Setuju \\
\hline Y.5 & 126 & 4.3 & V & Sangat setuju \\
\hline Y.6 & 124 & 4.3 & IV & Sangat setuju \\
\hline Y.7 & 127 & 4.4 & V & Sangat setuju \\
\hline
\end{tabular}

Sumber : Data olahan 2013

3. Uji Validitas dan Reliabilitas

Tabel 4.3

Uji Validitas dan Reliabilitas Data

\begin{tabular}{|l|r|r|r|}
\hline & $\left(\mathrm{X}_{1}\right)$ & \multicolumn{1}{c|}{$\left(\mathrm{X}_{2}\right)$} & \multicolumn{1}{l|}{$\mathrm{Y})$} \\
\hline Corrected Item-Total Correlation P1 & .373 & .632 & .746 \\
\hline Corrected Item-Total Correlation P2 & .700 & .860 & .826 \\
\hline Corrected Item-Total Correlation P3 & .753 & .817 & .713 \\
\hline Corrected Item-Total Correlation P4 & .805 & .757 & .845 \\
\hline Corrected Item-Total Correlation P5 & .860 & .917 & .767 \\
\hline Corrected Item-Total Correlation P6 & .732 & .863 & .755 \\
\hline Corrected Item-Total Correlation P7 & .735 & .804 & .647 \\
\hline Cronbach's Alpha & .784 & .798 & .792 \\
\hline
\end{tabular}

Sumber : Data Hasil Olahan SPSS

Hasil uji validitas dan reliabilitas untuk pertanyaan 1-7 untuk variabel $\mathrm{X}_{1} \mathrm{X}_{2}$ dan $\mathrm{Y}$, mempunyai nilai korelasi di atas 0,30 dan rata-rata nilai cronbach alpha 0,791. Semua dinyatakan reliabel dan valid.

4. Uji Asumsi Klasik

1) Uji Normalitas

\section{Gambar 4.1 Uji Normalitas}

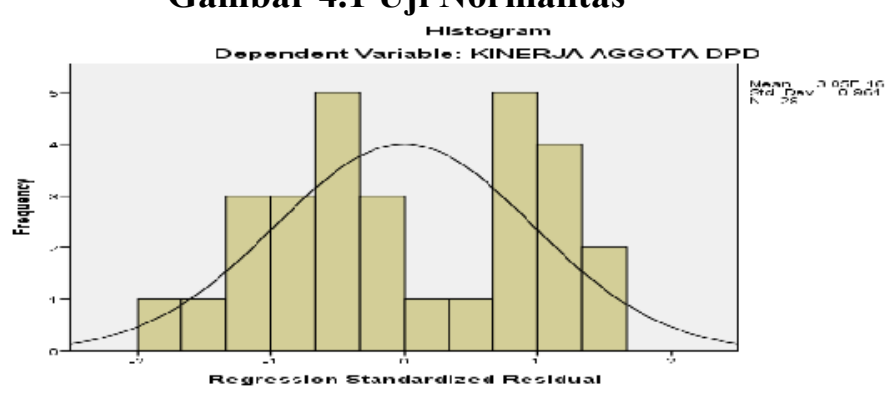


Gambar 4.1 menunjukan kurva normal pada histogram maka dapat diambil kesimpulan bahwa model memiliki distribusi normal, hal ini diperlihatkan oleh bentuk kurva yang menyerupai lonceng, bell shaped.

2) Uji Multikolinearitas

Tabel 4.4

Hasil uji multikolinearitas

Coefficientsa

\begin{tabular}{|c|c|c|c|c|c|}
\hline \multirow[b]{2}{*}{ Model } & \multicolumn{3}{|c|}{ Correlations } & \multicolumn{2}{|c|}{$\begin{array}{l}\text { Collinearity } \\
\text { Statistics }\end{array}$} \\
\hline & Zero-order & Partial & Part & Tolerance & VIF \\
\hline $1 \quad$ (Constant) & & & & & \\
\hline $\begin{array}{l}\text { Latar Belakang } \\
\text { Pendidikan }\end{array}$ & .614 & .013 & .008 & .411 & 2.431 \\
\hline Pengalaman Politik & .794 & .638 & .504 & .411 & 2.431 \\
\hline
\end{tabular}

Sumber : Data Hasil Olahan SPSS, 2013

Suatu model dapat dikatakan tidak terjadi Multikolineritas, jika nilai variance inflation factor $(\mathrm{VIF})<10$ dan nilai tolerance $>0,10$. Berdasarkan hasil coefficients yang terdapat pada tabel 4.4 dapat dilihat bahwa output coefficients model tidak terjadi gejala multikolinearitas.

3) Uji Heteroskedastisitas
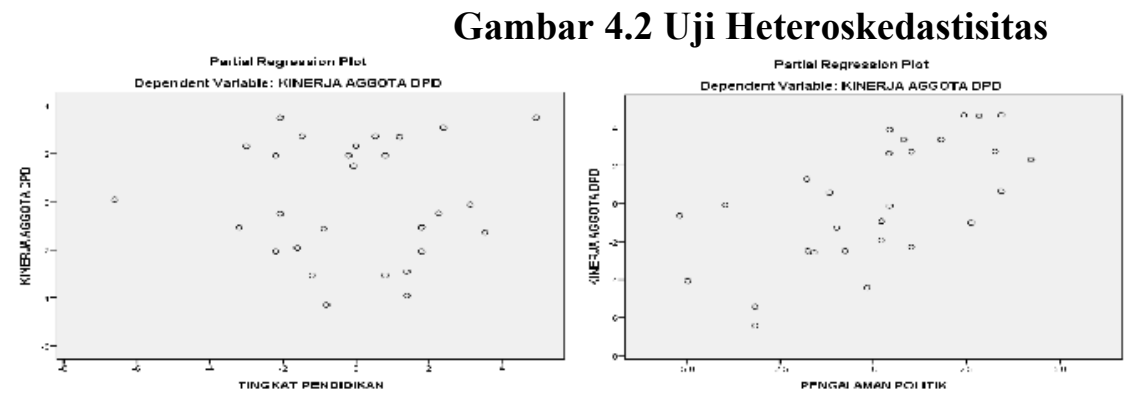

(Sumber : Data Hasil Olahan SPSS)

Pada gambar 4.2 dapat dilihat bahwa titik-titik data tidak membentuk suatu pola yang jelas, serta titik-titik data menyebar di atas dan di bawah angka 0 (nol) pada sumbu $\mathrm{Y}$, hal ini menunjukan tidak terjadi heteroskedastisitas

4) Uji Autokorelasi

Tabel 4.5

Hasil uji autokorelasi

Model Summaryb

\begin{tabular}{|c|c|c|c|c|c|c|}
\hline \multirow[b]{2}{*}{ Model } & \multicolumn{5}{|c|}{ Change Statistics } & \multirow{2}{*}{$\begin{array}{l}\text { Durbin- } \\
\text { Watson }\end{array}$} \\
\hline & $\begin{array}{c}\text { R Square } \\
\text { Change }\end{array}$ & $\begin{array}{c}\mathrm{F} \\
\text { Change }\end{array}$ & df1 & $\mathrm{df} 2$ & $\begin{array}{c}\text { Sig. F } \\
\text { Change }\end{array}$ & \\
\hline 1 & .631 & 22.228 & 2 & 26 & .000 & 1.664 \\
\hline
\end{tabular}

a. Predictors: (Constant), Pengalaman Politik, Latar Belakang Pendidikan

b. Dependent Variable: Kinerja DPRD Dalam Pengawasan Pengelolaan

Keuangan Daerah/APBD

Sumber : Data Hasil Olahan SPSS, 2013 
Suatu model dapat dinyatakan tidak terjadi gejala autokorelasi, jika probabilitas nilai DurbinWatson $>0,05$. Nilai Durbin Watson pada tabel 4.21 adalah 1,664, dengan demikian maka dapat dipastikan bahwa model tersebut tidak mengalami gejala autokorelasi.

5. Analisis Regresi Linear Berganda

Tabel 4.6

Koefisien Regresi

Latar Belakang Pendidikan dan Pengalaman Politik

Coefficients $^{\mathrm{a}}$

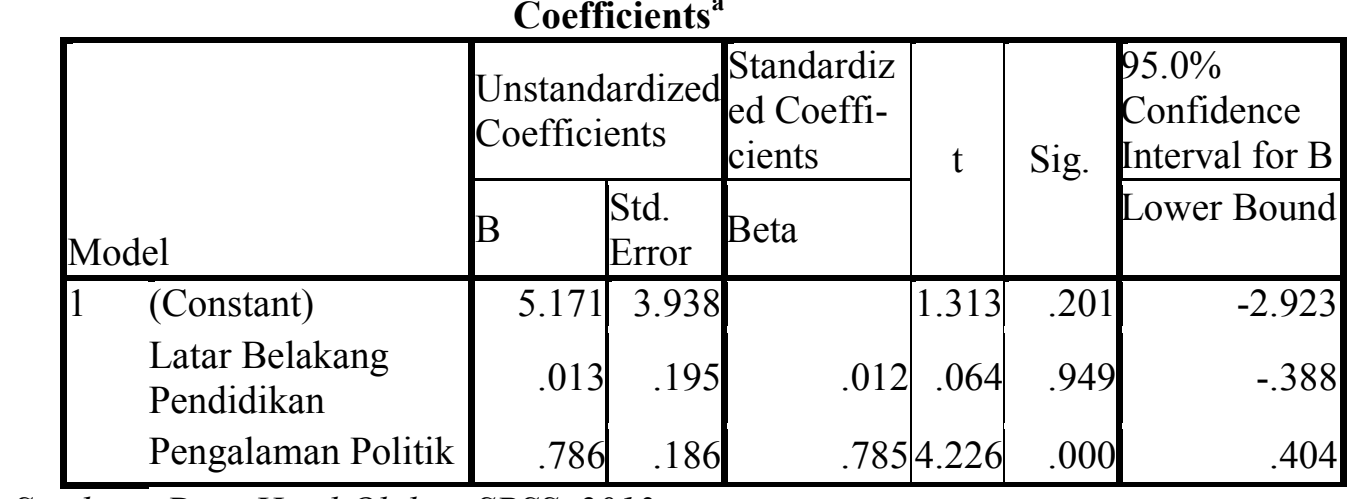

Sumber : Data Hasil Olahan SPSS, 2013

Persamaan regresi berdasarkan hasil perhitungan software SPSS 19 pada tabel 4.6, adalah sebagai berikut :

$\mathrm{Y}=5,171+0,13 \mathrm{X}_{1}+0,786 \mathrm{X}_{2}+\mathrm{e}$

Dengan interpretasi bahwa :

Konstanta $\alpha$ sebesar 5,171 memberikan pengertian bahwa jika pendidikan (X1), dan pengalaman politik (X2), sama dengan nol (0), maka kinerja DPRD dalam pengawasan pengelolaan keuangan daerah/APBD di DPRD Kota Sorong adalah 5.171 satuan skor.

Variabel latar belakang pendidikan (X1), memiliki nilai koefisien regresi ( $\beta$ ) sebesar 0,013 , ini berarti bahwa jika variabel lain nilainya tetap atau tidak berubah, maka setiap kenaikan 1 poin (1\%) variabel latar belakang pendidikan (X1), akan meningkatkan nilai kinerja DPRD dalam pengawasan pengelolaan keuangan daerah/APBD sebesar 0,013 dari kondisi sebelumnya. Koefisien variabel latar belakang pendidikan (X1), bernilai positif, artinya terdapat hubungan positif antara (X1) latar belakang pendidikan dengan (Y) kinerja DPRD dalam pengawasan pengelolaan keuangan daerah/APBD. Artinya bahwa semakin meningkat nilai latar belakang pendidikan (X1), maka akan meningkatkan kinerja DPRD dalam pengawasan pengelolaan keuangan daerah/APBD (Y) di DPRD Kota Sorong.

Variabel pengalaman politik (X2), memiliki nilai koefisien regresi $(\beta)$ sebesar 0,786 , ini berarti bahwa jika variabel lain nilainya tetap atau tidak berubah, maka setiap kenaikan 1 poin (1\%) variabel pengalaman politik (X2), akan meningkatkan nilai kinerja DPRD dalam pengawasan pengelolaan keuangan daerah/APBD sebesar 0,786 dari kondisi sebelumnya. Koefisien variabel pengalaman politik (X2), bernilai positif, artinya terdapat hubungan positif antara (X2) pengalaman politik dengan (Y) kinerja DPRD dalam pengawasan pengelolaan keuangan daerah/APBD. Artinya bahwa jika pengalaman politik (X2) semakin meningkat maka akan meningkatkan kinerja DPRD dalam pengawasan pengelolaan keuangan daerah/APBD (Y) di DPRD Kota Sorong.

6. Pengujian Hipotesis dengan Uji t

Menggunakan tabel 4.6 dapat diketahui hasil uji t untuk masing-masing variabel secara parsial yaitu nilai koefisien regresi X1 memiliki tingkat signifikansi 0,949, nilai ini lebih besar dari 0,05 (sig $>\alpha$ atau 0,949 > 0,05); apabila menggunakan nilai t-hitung dibandingkan dengan t-tabel dapat diketahui bahwa nilai t- hitung sebesar 0,064 lebih kecil dari nilai t-tabel sebesar 2,056 (t-hitung < 
t-tabel atau 0,064<2,056). Hal ini berarti bahwa Variabel Latar Belakang Pendidikan (X1) tidak berpengaruh terhadap Kinerja DPRD Dalam Pengawasan pengelolaan Keuangan Daerah/APBD di DPRD Kota Sorong.

Nilai koefisien regresi X2 memiliki tingkat signifikansi 0,000, nilai ini lebih kecil dari 0,05 (sig $<\alpha$ atau $0,000<0,05$ ); apabila menggunakan nilai t-hitung dibandingkan dengan t-tabel dapat diketahui bahwa nilai t hitung sebesar 4,226 lebih besar dari nilai t-tabel sebesar 2,056 (t-hitung $>$ t-tabel atau $4,226>2,056$ ). Hal ini berarti bahwa Variabel Pengalaman Politik (X2) berpengaruh terhadap Kinerja DPRD Dalam Pengawasan Pengelolaan Keuangan Daerah/APBD di DPRD Kota Sorong.

7. Koefisien Korelasi dan Determinasi

Tabel 4.23

Hasil uji koefisen korelasi dan determinasi Model Summary ${ }^{\mathrm{b}}$

\begin{tabular}{|c|c|c|c|c|}
\hline Model & $\mathrm{R}$ & R Square & $\begin{array}{c}\text { Adjusted R } \\
\text { Square }\end{array}$ & $\begin{array}{c}\text { Std. Error of the } \\
\text { Estimate }\end{array}$ \\
\hline 1 & $.794^{\mathrm{a}}$ & .631 & .603 & 2.484 \\
\hline
\end{tabular}

Sumber : Data Hasil Olahan SPSS, 2013

Tabel 4.23 menunjukan bahwa koefisien korelasi linier ${ }^{\circledR}$ yang dihasilkan diantara variabel bebas adalah sebesar 0,794 . Nilai korelasi (R) sebesar 0.794 menunjukkan bahwa adanya hubungan yang kuat antara variabel X1 dan X2 dengan variabel Y. Sedangkan nilai Adjusted R Square atau koefisien determinasi $\left(\mathrm{R}^{2}\right)$ sebesar 0.603 menunjukkan bahwa kontribusi variabel $\mathrm{X} 1$ dan $\mathrm{X} 2$ untuk menjelaskan model variabel $\mathrm{Y}$ adalah sebesar $60,3 \%$ sedangkan sisanya sebanyak $39,7 \%$ dijelaskan oleh variabel lain yang tidak dimasukkan dalam model penelitian ini.

\subsection{Evaluasi Data}

1. Latar Belakang Pendidikan terhadap kinerja DPRD dalam Pengawasan Pengelolaan Keuangan Daerah/APBD pada DPRD Kota Sorong

Hasil analisis regresi terhadap hipotesis pertama dapat dilihat bahwa latar belakang pendidikan tidak berpengaruh terhadap kinerja DPRD dalam pengawasan pengelolaan keuangan daerah/APBD. Latar Belakang Pendidikan tidak berpengaruh, karena kurang didukung oleh tingkat kompetensi dan ketidakkesesuaian bidang pendidikan yang dimiliki anggota dewan dengan bidang tugasnya. Anggota dewan sebagian besar berasal dari bidang pendidikan diluar bidang ekonomi secara khusus bidang akuntansi. Oleh karrena itu untuk meningkatkan pemahaman tentang pengawasan keuangan daerah/APBD agar kinerja semakin baik, maka selain pengalaman anggota dewan diharapkan dapat mengikuti pelatihan/seminar mengenai penyusunan anggaran dan pengawasan anggaran.

2. Pengalaman Politik terhadap kinerja DPRD dalam pengawasan pengelolaan keuangan daerah/APBD pada DPRD Kota Sorong.

Hasil analisis regresi terhadap hipotesis ke dua dapat dilihat bahwa Pengalaman Politik berpengaruh terhadap kinerja DPRD dalam pengawasan pengelolaan keuangan daerah/APBD. Pengalaman merupakan modal yang sangat berharga bagi seseorang untuk meningkatkan kompetensinya. Berbekal pengalaman seseorang akan lebih memahami tugas dan tanggungjawabnya dan dalam melaksanakan tugas atau pekerjannya ia akan melaksanakanya lebih baik bila dibandingkan dengan mereka yang belum berpengalaman. 


\section{PENUTUP}

\subsection{Simpulan} berikut :

Dari hasil penelitian dan pembahasan maka dapat disimpulkan beberapa kesimpulan sebagai

1. Berdasarkan uji t Latar Belakang Pendidikan $\left(\mathrm{X}_{1}\right)$ tidak berpengaruh terhadap kinerja DPRD dalam pengawasan pengelolaan keuangan daerah/APBD (Y).

2. Sedangkan pengalaman politik $\left(\mathrm{X}_{2}\right)$ berpengaruh terhadap kinerja DPRD dalam pengawasan pengelolaan keuangan daerah/APBD (Y).

\subsection{Saran}

Dari hasil penelitian ini penulis menyarankan agar supaya sebagai berikut :

1. Sebagai salah satu bahan kajian bagi anggota DPRD untuk meningkatkan kinerja DPRD dalam pengawasan keuangan daerah sangat diperlukan pengetahuan dan kemampuan tentang anggaran, maka disarankan agar seluruh anggota DPRD yang berkaitan dengan pengawasan dan anggaran diberikan pelatihan guna meningkatkan kemampuan DPRD dalam pengawasan keuangan daerah/APBD. Pelatihan merupakan salah satu faktor dari pendidikan yakni pendidikan nonformal.

2. Guna memudahkan fungsi pengawasan, sebaiknya DPRD dapat menyelenggarakan kerja sama dengan institusi di luar DPRD seperti perguruan tinggi, yang memiliki tenaga ahli di bidangnya masing-masing. Tenaga ahli ini bertugas melakukan pengkajian guna memberikan masukan bagi DPRD. Dengan menggunakan hasil kajian ini diharapkan DPRD tidak salah dalam melaksanakan fungsi dan tugas pokoknya pada saat pengambilan keputusan.

\section{DAFTAR PUSTAKA}

BAPEDA Kota Sorong, Profil Kota Sorong, 2010

Darise, N., Pengelolaan Keuangan Pada Satuan Kerja Perangkat Daerah (SKPD) dan BLU, Edisi Kedua, dicetak dan dijilid oleh PT. Mancanan Jaya Cermelang, Indeks, Jakarta 2009

Mahsun, Moh.,Pengukuran Kinerja Sektor Publik, Edisi Pertama, Penerbit BPFE Yogyakarta., Cetakan Ketiga Januari 2012

Mardiasmo, Akuntansi Sektor Publik, Edisi IV, Penerbit ANDI Yogyakarta, 2009.

Masyhuri, Zainuddin, M., Metodologi Penelitian Pendekatan Praktis dan Aplikatif, Cetakan kedua, Penerbit PT. Refika Aditama Bandung, 2009.

Nordiawan D. Putra I.S dan Rahmawati M., Akuntansi Pemerintahan, Penerbit Salemba Empat, 2012

Nordiawan D. dan Hertianti A., Akuntansi Sektor Publik, Edisi 2, Penerbit Salemba Empat, 2012

Riduwan \& Sunarto, Pengantar Statitika, untuk penelitian Pendidikan, Sosial, Komnikasi dan Bisnis, Penerbit ALFABETA, Bandung, Cetakan ketiga 2010

Republik Indonesia, Undang-Undang No. 22 Tahun 1999 tentang Pemerintah Daerah, 1999

Republik Indonesia, Undang-Undang No.25 Tahun 1999 tentang Perimbangan Keuangan antara Pemerintah Pusat dan Daerah, 1999

Republik Indonesia, Keputusan Presiden No.74 tahun 2001 tentang Tata Cara Pengawasan Penyelenggaraan Pemerintahan Daerah, 2001

Republik Indonesia, Kepmendiknas nomor 045/U/2002 Tentang Kurikulum Inti Pendidikan Tinggi, 2002

Republik Indonesia, Undang-Undang No 13 tahun 2003 tentang Ketenagakerjaan, 2003 
Republik Indonesia, Undang-Undang No. 32 Tahun 2004 tentang Pemerintahan Daerah cq. UU No. 12 Tahun 2008 tentang Perubahan Kedua atas UU No. 32 Tahun 2004 tentang Pemerintahan Daerah, 2004

Republik Indonesia, Undang-Undang No. 33 Tahun 2004 tentang Perimbangan Keuangan antara Pemerintah Pusat dan Daerah., 2004

Republik Indonesia, Peraturan Pemerintah No. 58 Tahun 2005 tentang Pengelolaan keuangan Daerah., 2005

Republik Indonesia, Peraturan Menteri Dalam Negeri, Nomor 13 Tahun 2006, tentang, Pedoman Penelolaan Keuangan Daerah., 2006

Republik Indonesia, Peraturan Menteri Dalam Negeri, Nomor. 30 Tahun 2007 tentang Pedoman Penyusunan Anggaran Pendapatan dan Belanja Daerah Tahun Anggaran 2008., 2007

Republik Indonesia, Undang-Undang Nomor 27 Tahun 2009, tetang MPR, DPR, DPD dan DPRD., 2009

Sari I., Pengaruh Personal Background dan Political Background Serta Pengetahuan Dewan Tentang Anggaran Terhadap Kinerja DPRD Dalam Pengawasan Keuangan Daerah/APBD., 2010

Sarjono, Haryadi \& Winda Julianita... SPSS vs LISREL Sebuah Pengantar, Aplikasi untuk Riset. Jakarta : Salemba Empat., 2011

Wahjono, S. I., Perilaku Organisasi, Penerbit : Graha Ilmu, 2006.

Wardayani, Pengaruh Pengetahuan Dewan Tentang Anggaran, Partisipasi Masyarakat dan Transparansi Kebijakan Publik Terhadap Kinerja DPRD Dalam Pengawasan Keuangan Daerah Dengan Komitmen Profesional Sebagai Variabel Moderasi., 2010,

Winarna J dan Murni, S., Pengaruh Personal Background, Political Background dan Pengetahuan Dewan Tentang Anggaran Terhadap Peran DPRD Dalam Pengawasan Keuangan Daerah, Simposium Nasional Akuntansi X, Unhas Makasar., 2007

Wibowo. A.E., Aplikasi Praktis SPSS Dalam Penelitian, Penerbit Gava Media Yogyakarta., 2012.

Yacob A, Pengaruh Pengetahuan Anggaran dan Jenjang Pendidikan Serta Latar Belakang Pendidikan Terhadap Kinerja Panitia Anggaran-DPRD., 2007 